\title{
Study on blood gases, Acid-Base balance and the therapeutic evaluation of different protocol of treatment of mastitic cows.
}

\author{
Abdulkarim Jafar Karim \\ College of Vet. Medicine- University of Baghdad
}

Summary

This study was planned to reveal the changes in blood gases and acid-base values in mastitic cows and to state the intravenous fluid therapy regimen treatment. A herd with a population of 150 lactating cows was screened for clinical and subclinical mastitis for a period of 6 months. Based on inclusion and exclusion criteria, twenty-eight cows with clinical mastitis were divided in three groups (mastitic not treated (group $\mathrm{M}$ ), mastitic treated with antibiotic only (group TA) and mastitic treated with antibiotic and fluid therapy (group TAF) and another five healthy cows (group C) served as controls. Blood gases, SCC, CMT scores, udder health status and cure rate were carefully investigated. There was significant differences between $\mathrm{PO}_{2}, \mathrm{PCO}_{2}, \mathrm{BE}$, and $\mathrm{HCO}_{3}{ }^{-}$concentration in mastitic cows. Increased $\mathrm{pH}, \mathrm{BE}$, and $\mathrm{HCO}_{3}{ }^{-}$referred to metabolic alkalosis whereas increased $\mathrm{PCO}_{2}$ indicate compensatory respiratory acidosis. The results of SCC in milk agreed to CMT scores, and to some extent to udder health status among the entire period of study. Cure rate was earlier in group TAF with less number of treatment than in group TA. It has been concluded from this study that administration of fluid therapy might be useful as an adjunct in case of clinical mastitis in cows to get quick clinical recovery with less number of treatments. However, the role of blood gases and acid - base status in mastitis should be investigated in details.

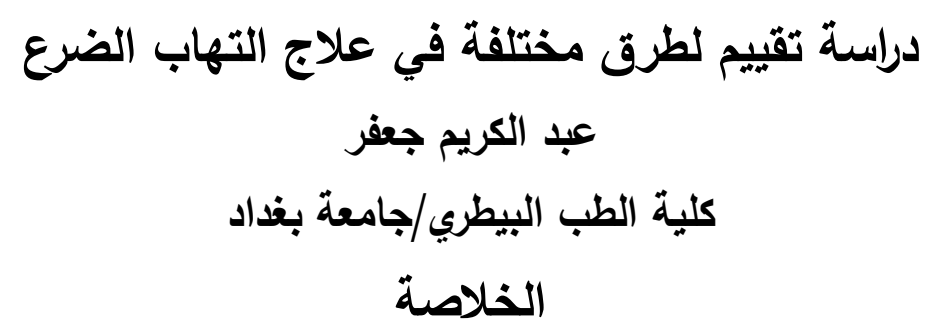

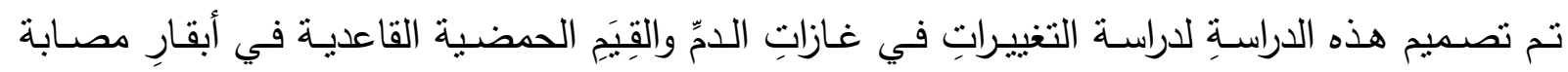

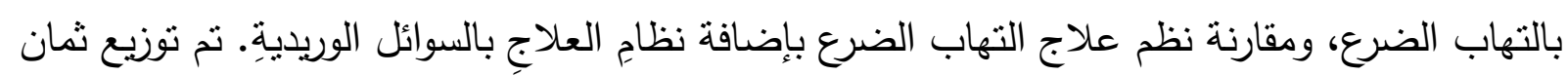
وعشرون بقرة مصابة بالتهاب الضرع السريريٍ في ثلاث مجموعاتِ (المجموعة الأولى وتضم سبعة أبقار

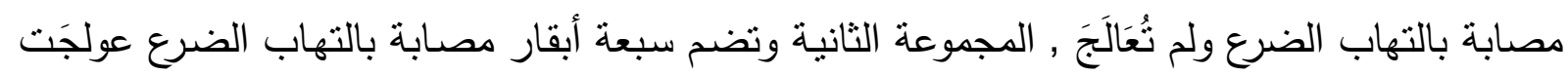

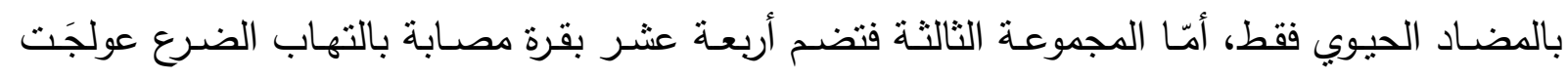

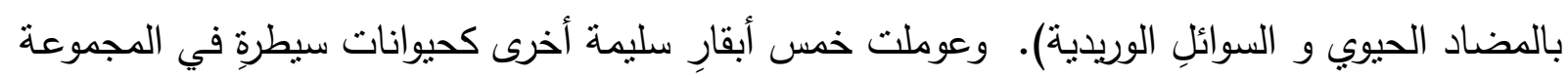


الرابعـة. تمت دراسـة نسبة غازات الدم ، عد الخلايـا البيضـاء في الحليب ، اختبار كاليفورنيا لإلتهاب

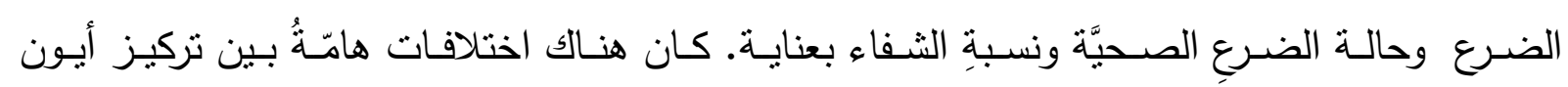

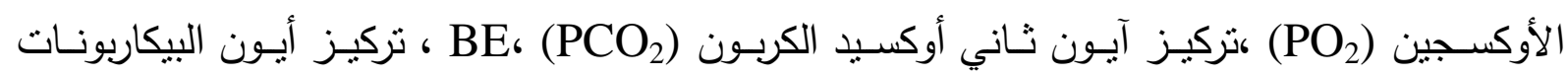

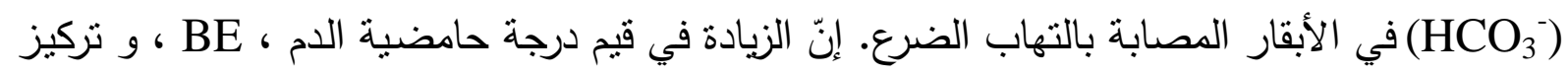
آيون البيكاربونات يشير الى قاعدية الدم الأيضية metabolic alkalosis بينما يشير زيادة

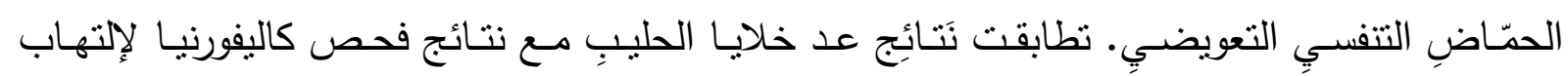

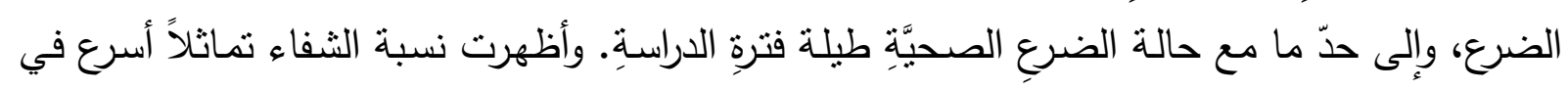

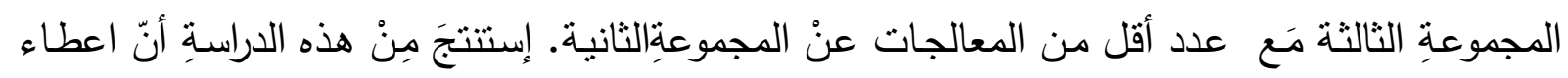

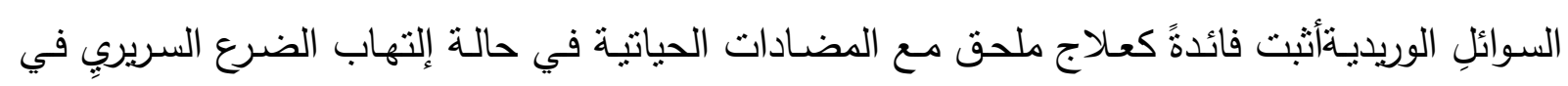

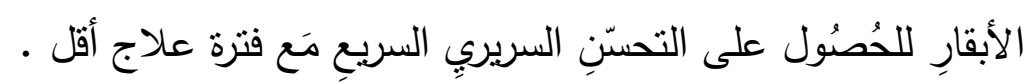

\section{Introduction}

Mastitis continues to be a problem of serious concern for dairy industry as well as public health throughout the world. The annual incidence of this disease in Iraq is as high as $70.6 \%$ for subclinical mastitis (1). Subclinical mastitis causes $18 \%$ and clinical form causes $50 \%$ milk loss in dairy cows (2). Moreover, economic importance is revealed by milk dumped for antibiotics, veterinary costs, labor costs, poor conditioned suckling calves, culling and death costs, and lost milk premiums through i.) Increased somatic cell counts, ii.) Decreased fat, and iii.) Decreased protein. It seems to be the most prevalent (35 to 40 cases/year per 100 cows) and the most costly disease in dairy cattle in the USA with losses exceeds $\$ 2$ billion/year $(3,4)$.

Multidisciplinary approaches have been undertaken in recent years to find out a suitable remedy. In addition to that intramammary infusion of antibiotics has been reported to suprpress the various activities of infiltrated polymorphnuclear leukocytes (PMNL) in mastitis udder (5), none of the available antibiotics have been proven to have more than $60 \%$ efficacy in field conditions against major mastitis pathogens (2) and the use of fluid therapy was often excluded.

Consideration the changes in blood gases and acid base values, which seem the more important point in stating the fluid therapy as a line of treatment in conjunction with antibiotics, has been usually missed, with the exception of the treatment of E.coli mastitis, in which the fluid therapy focused to treat the accompanied toxaemia (2). Therefore the aim of this study is to reveal data on acid-base balance in mastitic cows and to insure a prompt treatment. 


\section{Materials and Methods}

Animals: 150 healthy cows from small herds, in Abu-Ghraib village, 30 kilometers west to Baghdad, from early May to the end of October 1989, fed on balance ration, were put under clinical supervision. Hand milking was performed twice daily and there was no milking machine. Washing of udder with tape water before each milking was performed regularly. Teat dipping was not practiced regularly. General (including udder) health status and data of SSC, $\mathrm{CMT}, \mathrm{PO}_{2}, \mathrm{PCO}_{2}, \mathrm{pH}, \mathrm{HCO}_{3}{ }^{-}$and $\mathrm{BE}$ were recorded to fix the normal (preinfection) values of all cows.

Selection of study animals was based on inclusion (Age: 4 to 7 years, Lactation: 2 nd to $5^{\text {th }}$, Stage of lactation: 15 th day to $4^{\text {th }}$ month, Milk yield: $>10$ liters, Breed: Crossbred of Friesian with indigenous breed) and exclusion (First 15 days or later stage of lactation, History of prior infection in any quarter or any major health problem in present lactation, Presence of skin lesions on teat, Chronic or Peracute form of mastitis) criteria.

Out of the 150 cows examined, the prevalence of mastitis was $(57.3 \%)$ considerably high in this study, and in 6 months period 86 cases of mastitis ( sbclinical=58, clinical=28) were diagnosed. From the 86 mastitis cows twenty eight cows each with clinical mastitis, and five cows separately with normal udder and health were selected as study animals

Chemicals:

Ampiclox (Ampicillin plus Cloxacillin) (Beecham Pharmaceuticals, Brentford, England).

Glucose saline (from MIV: Mosul IntraVenous Project, Mosul, Iraq).

Experimental design:

Table 1 shows protocol for therapeutic evaluation of antibiotic therapy plus fluid therapy in mastitic cows. Five healthy animals with normal udder and milk served as healthy control (group C). Twenty-eight cows with clinical mastitis were divided into group $M(n=7$, mastitic cows not treated), group TA $(n=7$, mastitic cows treated with antibiotic only), and group TAF $(n=14$, mastitic cows treated with antibiotics and fluid therapy).

All cows were subjected to daily routine clinical examination including udder health status (swelling, pain reflex measured by pressing the udder with the help of fingers) and milk yield was estimated. Arterial blood samples were taken at healthy status (pre-infection), during infection, and 14 days after infection to determine the partial pressure of oxygen $\left(\mathrm{PO}_{2}\right)$ and carbon dioxide $\left(\mathrm{PCO}_{2}\right), \mathrm{pH}$, bicarbonate $\left(\mathrm{HCO}_{3}{ }^{-}\right)$concentration and base excess $(\mathrm{BE})$ using a blood gas analyzer (Acid-base calculator: Inst. Lab. Italy), in the Department of 
Surgery- Collage of Vet. Medicine, Baghdad.

Sampling: 2-3 ml of blood from common carotid artery was taken $3-5 \mathrm{~cm}$ foreword the thoracic inlet in the jugular groove. Heparinised syringe was used. Needle fitted to the syringe was injected in vertical position to the artery. Moving the depth of the needle inside tissues without pulling the pistol of the syringe, blood will soon fill the syringe by the cardiac pumping force without any bubble appear in the sample (anaerobically). Samples were handled in an ice water bath and checked in the laboratory within 30 minutes (6).

Screening for mastitis and evaluation of treatment:

Diagnosis and classification of mastitis were based on physical examination of the udder; physical and chemical changes in the milk, California mastitis test (CMT) score of affected quarter. Milk Somatic Cell Count (SCC) was carried on in a healthy status, during infection, 5 and 14 days post infection. Subclinical mastitis was diagnosed on the basis of CMT score and SCC. The CMT was carried out at cow side at the time of milking by mixing $3 \mathrm{ml}$ of fresh milk with equal volume of CMT reagent. The milk and CMT reagent were mixed together by swirling the paddle or by stirring with a glass rod and the results were read after 10-15 seconds. Interpretation of CMT results was carried according to (2). Standard procedures (7) were followed to collect the milk for SCC and CMT. Data were statistically analyzed using analysis of variance (ANOVA) and student's t-test $(\mathrm{P}<0.05)(8)$.

\section{Results}

Udder health status, Milk SCC, CMT reaction, treatment duration and cure rate are shown in Table 2. Animals of group TAF showed faster recovery and required less number of antibiotic treatments than the group TA. The cure rate was $100 \%$ on day 6 in group TAF, and $85.7 \%$ on day 14 in group TA. Duration of antibiotic treatment was longer in group TA (5 days) than in group TAF (3 - 4 days). The effect of fluid therapy was apparent, the milk from quarters of group TAF showed moderate $(++)$ and (-) while quarters of group TA showed severe (+++) and (+) reaction to CMT on the 2nd and 6th day of treatment respectively. Records of udder health status showed severe swelling, pain reflex and physical changes in milk in all quarters of all groups at the first day post treatment. Swelling of the quarters remained severe in group TA on the day 2 and tend to be moderate, mild, and normal on days 3, 4 and 14 respectively. The normal size of the quarters in group TAF was clear on day 5 . There was moderate pain reflex in quarters of group TA on day 2 and became mild and nil on days 3 and 6 respectively, while it was mild on days 2,3 and nil on day 4 in group TAF. 
Physical changes in milk became moderate, mild to nil on days 2,3,6 in group TA and mild to nil on days 2, 5 in group TAF respectively. Normal milk yield was achieved on day 14 in TAF group, while there was $7 \%$ milk loss in group TA. Somatic cell counts $(\mathrm{SCC})$ of milk increased significantly $(\mathrm{P}<0.05)$ during infection in all groups. There was gradual decrease in SCC on day 5 postinfection in groups TA and TAF, and the data was still showing a significant high values $(\mathrm{P}<0.05)$ from the pre- infective stage in groups $\mathrm{TA}$ and $\mathrm{M}$ two weeks post-infection, while normal level was observed in group TAF.

Results of the blood gases and acid-base values are shown in Table 3. There were significant increases $(\mathrm{P}<0.05)$ in $\mathrm{PO} 2, \mathrm{PCO} 2$, and $\mathrm{HCO} 3-$ concentration in all cows during mastitis compared with the pre-infective stage accompanied by slight increase in $\mathrm{pH}$. These values showed a significant increase in group $\mathrm{M}$ two weeks post infection, with a tendency to slight increase and normal in group TA and TAF respectively.

\section{Discussion}

Duration of treatment was less frequent in group TAF than in group TA. The use of antibiotic therapy alone in bovine mastitis suppresses the functions of PMN Leukocytes of mammary gland $(5,9)$. Fluid therapy in conjunction with antibiotic may have the ability to treat toxaemia and severe infection (2) accompanying mastitis, and so, general animal health including the udder health status could be improved faster. This was also manifested by earlier clinical cure rate in group TAF compared with group TA. The results of SCC in milk agreed to CMT scores among the entire period of study. The CMT reagent (Sodium arylalkyl sulphonate) causes the increased leukocytes (nucleic acids) in mastitic milk to form a gel (7).

The technique of sampling arterial blood in cattle could be applied from brachial, saphenous, coccygeal, and the auricular arteries, but the common carotid artery might be an easier and perfect method (10). Acid-base disorders of the blood (metabolic acidosis, metabolic alkalosis, respiratory acidosis, and respiratory alkalosis) depend primarily upon the ratio between bicarbonate $\left(\mathrm{HCO}_{3}\right)$ and $\mathrm{PCO}_{2}$ in blood $\left(\mathrm{HCO}_{3} / \mathrm{H}_{2} \mathrm{CO}_{3}\right.$ system $)(11)$. On applying the Henderson-Hasselbach equation (11), metabolic alkalosis is a prominent criterion in the mastitic cows in this study. It might be concluded that the more chloride ion secreted in the mastitic milk (12) resulted in more $\mathrm{HCO}_{3}$ diffusion in the plasma. This result is agreed to that seen in mastitic ewes (13) with no any suggestion for the use of fluid therapy but only in cases of peracute coliform mastitis in cows (2). As per author's knowledge no study has been reported on the acid-base status of the blood in cows affected with mastitis in Iraq and very little worldwide (14), while many studies referred that acid-base status might be 
affected by pathological conditions, e.g., carbohydrate intake, diarrheoa, intestinal strangulation, abomasal displacement, and physiological conditions, e.g., stage of pregnancy, calving and grazing seasons, breeds with climate, sex, highest yielding cows (2).

The pathogenesis of mastitis starts from a damage to glandular tissue followed by invasion, colonization and infection. Infection results in further damage of mammary tissue, which should heal quickly by an effective therapy. Healing can take place only when sufficient amount of collagen is being synthesized by system(15). This process might be affected when any disturbance in the acid - base status referring to a disturbed metabolism. It was observed that SOD (Super Oxide Dismutase) is intracellular superoxide escaping from the neutrophil could damage surrounding tissue and cause inflammatory disease (16). Interstitial fluid, unlike the enzyme, is not limited to the cell and could serve as a proper media for metabolic processes. Antibiotics alone (in group TA) are less effective after the development of clinical signs as the multiplication of bacteria slowed down considerably $(17,18)$. It has become further easy to accept that faster recovery in clinical mastitis and the normal return of $\mathrm{PCO}_{2}, \mathrm{HCO}_{3}$ and $\mathrm{BE}$ in group TAF two weeks post infection could be attributed to administration of fluid therapy which maintain the metabolic processes.

The significant differences between $\mathrm{SCC}, \mathrm{PCO}_{2}, \mathrm{HCO}_{3}, \mathrm{BE}$ in group TA and the normal return in group TAF, in addition to the udder health status and CMT scores two weeks post infection, give a conclusion, that the administration of fluid therapy might be useful as an adjunct in case of clinical mastitis in cows to get quick clinical recovery with less number of treatments. However, the role of blood gases and acid - base status in mastitis should be investigated in details. 
Iraqi Journal of Veterinary Medicine Vol. 29, No.2, 2005 
Iraqi Journal of Veterinary Medicine Vol. 29, No.2, 2005 
Table 3: Arterial pH, $\mathrm{PO}_{2}, \mathrm{PCO}_{2}$, bicarbonate $\left(\mathrm{HCO}_{3}{ }^{-}\right)$and base excess (BE) in mastitic cows (mean \pm S.D.).

\begin{tabular}{|c|c|c|c|c|}
\hline Parameters & Animal groups & Pre-infection & During infection & 2 weeks post infection \\
\hline \multirow{4}{*}{$\begin{array}{c}\mathrm{PO}_{2} \\
(\mathrm{~mm} \mathrm{Hg})\end{array}$} & $\mathbf{M}$ & $91.28 \pm 3.85$ & $* 112.27 \pm 6.03$ & $* 100.11 \pm 4.34$ \\
\hline & TA & $93.50 \pm 4.12$ & * 110.91 \pm 5.21 & $95.84 \pm 3.17$ \\
\hline & TAF & $92.50 \pm 4.32$ & $* 113.26 \pm 6.27$ & $94.24 \pm 3.04$ \\
\hline & $\mathbf{C}$ & $89.66 \pm 2.81$ & $91.16 \pm 3.39$ & $93.22 \pm 2.56$ \\
\hline \multirow{4}{*}{$\begin{array}{l}\mathrm{PCO}_{2} \\
(\mathrm{~mm} \mathrm{Hg})\end{array}$} & $\mathbf{M}$ & $43.80 \pm 4.03$ & $* 59.61 \pm 2.15$ & $* 58.71 \pm 4.05$ \\
\hline & TA & $44.21 \pm 2.46$ & $* 58.72 \pm 2.35$ & $* 52.63 \pm 2.71$ \\
\hline & TAF & $41.32 \pm 6.22$ & $* 58.10 \pm 4.98$ & $43.17 \pm 3.48$ \\
\hline & $\mathbf{C}$ & $42.48 \pm 1.56$ & $41.96 \pm 1.59$ & $41.74 \pm 1.23$ \\
\hline \multirow{4}{*}{ pH } & $\mathbf{M}$ & $7.408 \pm 0.009$ & $* 7.577 \pm 0.010$ & $* 7.528 \pm 0.013$ \\
\hline & $\mathbf{T A}$ & $7.410 \pm 0.008$ & $* 7.572 \pm 0.017$ & $7.431 \pm 0.021$ \\
\hline & TAF & $7.407 \pm 0.016$ & $* 7.580 \pm 0.025$ & $7.402 \pm 0.034$ \\
\hline & $\mathbf{C}$ & $7.408 \pm 0.007$ & $7.410 \pm 0.006$ & $7.410 \pm 0.006$ \\
\hline \multirow{4}{*}{$\begin{array}{l}\mathrm{HCO}_{3}^{-} \\
(\mathrm{mEq} / \mathrm{L})\end{array}$} & $\mathbf{M}$ & $25.70 \pm 1.86$ & $* 36.14 \pm 1.95$ & $* 36.10 \pm 2.41$ \\
\hline & TA & $25.61 \pm 2.96$ & $* 37.06 \pm 2.36$ & * 31.87 \pm 2.72 \\
\hline & TAF & $27.66 \pm 3.42$ & $* 35.60 \pm 0.66$ & $25.98 \pm 0.68$ \\
\hline & $\mathbf{C}$ & $25.72 \pm 0.88$ & $25.50 \pm 1.12$ & $27.70 \pm 0.97$ \\
\hline \multirow{4}{*}{$\begin{array}{c}\text { BE } \\
(\mathrm{mEq} / \mathrm{L})\end{array}$} & $\mathbf{M}$ & $2.22 \pm 0.48$ & $* 10.02 \pm 1.47$ & * 9.54 \pm 1.35 \\
\hline & TA & $2.43 \pm 0.91$ & * $8.52 \pm 1.26$ & * 5.62 \pm 1.12 \\
\hline & TAF & $2.71 \pm 0.64$ & $* \quad 8.24 \pm 1.44$ & $2.02 \pm 0.80$ \\
\hline & $\mathbf{C}$ & $2.10 \pm 0.81$ & $2.24 \pm 0.58$ & $2.06 \pm 0.63$ \\
\hline
\end{tabular}

$M$ (group one)(n=7) mastitic cows not treated, TA (group two) (n=7) mastitic cows treated with antibiotics only, TAF (group three) $(n=14)$ mastitic cows treated with antibiotics and fluid therapy, $C$ (group four) $(n=5)$ controls.

* : Significantly different $(\mathbf{P}<0.05)$ from the corresponding pre-infection value 


\section{References}

1. Zorah, K.T. (1979). Some studies on clinical and bacteriological aspects of bovine mastitis. M.Sc. thesis, College of Veterinary Medicine. Baghdad. Iraq.

2. Radostitis, O. M., D.C. Blood and C.C. Gay. (1994). Veterinary Medicine. Bailliere Tindall, London.

3. Dobbins, C.N. (1977). Mastitis losses. J.Am. Vet. Med. Ass. 170:1129.

4. Blosser, T.H. (1979). Economic losses from and the national research program on mastitis in the United States. J. Dairy Sci. 62:119.

5. Hoeben, D., C. Burvenich and R. Heyneman. (1997). Influence of Antimicrobial agent on bactericidal activity of bovine milk polymorphonuclear leukocytes. Vet. Immunol. And Immunopathol. 56:271-282.

6. Haskins, S. (1977). Sampling and storage of blood for $\mathrm{pH}$ and blood gas analysis. J.A.V.M.A. 170:429-433.

7. Coles, E. (1986). Veterinary Clinical Pathology, 5th Ed. W.B. Saunders Company, Philadelphia. Pp.10-79.

8. Snedecor, G.W. and W.G. Cocharan. (1980). Statistical Methods. Iowa State University Press, Ames, Iowa, PP: 258-296.

9. Paape, M.J., R.H. Miller and G. Ziv. 1991. Pharmacologic enhancement or suppresion of phagocytosis by bovine neutrophils. Am. J. Vet. Res.52:363366.

10.Simpson, D.F., H.N. Erb and D.F. Smith. (1985). Base excess as a prognostic and diagnostic indicator in cows with abomasal volvulus or right displacement of the abomasum. Am. J. Vet. Res. 46(4)796-797.

11.West, J.B. (1977). Pulmonary pathophysiology. The Essentials. Williams and Wilkins, Baltimore, PP:20-41.

12.Reece, W.O. (1984). Acid-base balance and selected hematologic, electrolytic and blood chemical variables in calves nursing cows: one week through fifteen weeks. Am. J. Vet. Res. 45(4) 666-669.

13.Karim, A.J., F.K. Al-Ani and W.H. Dawood. (1993). Blood gases and acid-base values of sheep experimentally induced Pasteurella haemolytica mastitis. The Iraqi J. Vet. Med. Vol. 17:204- 209.

14.Erskine, R.J., Kirk, J.H., Tyler, J.W. and De Graves. (1993). Advances in the therapy for mastitis. Vet Clin. N. Am. 9(3): 499.

15.Eberhardt, R.J., R.J. Harmon , D.E. Jasper, R.P. Natzke, S.C. Nickerson, J.K. Reneau, E.H. Row, K.L. Smith, and S.B. Spencer. 1987. Current concept of bovine mastitis. 3rd ed. Natl. Mastitis Counc., Arlington, VA. 
16.Johnston, R. B. and J.E. Lehmeyer. 1977. EMBO workshop on superoxide and superoxide dismutase, (Ed. A.M.Michelson, J.M. McCord and I. Fridovich). Academic Press London. p. 291.

17.Craven, N. and J. C. Anderson. 1982. Experimental acute staphylococcal mastitis in the mouse.; The influence of pathological changes on the kinetics and therapeutic action of cloxacillin. J. Comp. Path. 92:579- 588.

18.Craven, N. 1987. Efficacy and financial value of antibiotic treatment of bovine clinical mastitis during lactation. British Vet. J. 143:410- 422. 